Article

KARGAR, M. ${ }^{1}$ (D)

GHORBANI, R. ${ }^{1 *}$

RASHED MOHASSEL, M.H. ${ }^{1}$

RASTGOO, M. ${ }^{1}$ (D

\section{Chlorophyll Fluorescence - A TOOl For Quick IDENTIFICATION OF ACCASE AND ALS INHIBITOR Herbicides Performance}

\author{
Fluorescência da Clorofila - Uma Ferramenta para Identificação Rápida do \\ Desempenho de Herbicidas Inibidores da Accase e da ALS
}

\begin{abstract}
Chlorophyll fluorescence measurement is a precise research technique that can be useel for studying the effect of herbicides with different modes of action on photosynthetic apparatus. The aim of the present project was to study the variation of the fluorescence induction curve (Kautsky curve) and its variables affected by pinoxaden (ACCase inhibitor) and mesosulfuron-methyl + iodosulfuron herbicide (ALS inhibitor) in littleseed canarygrass (Phalaris minor Retz.) and wild oat (Avena ludoviciana Durieu). This study was carried out at the Greenhouse of Collage of Agriculture at Ferdowsi University of Mashhad, during 2013. Experiments were performed based on a completely randomized design in form of a dose-response test with six doses of each herbicide plus an untreated control. The maximum quantum efficiency of photosystem II (PSII) was measured 1, 2, 3, 5 and 7 days after spraying (DAS). The results obtained in the study indicated that the estimated $\mathrm{ED}_{\mathrm{s}}$ parameters differed based on herbicide types or weed species. For example, $\mathrm{ED}_{90}$ varied from 11.67 to $28.61 \mathrm{~g}$ active ingredient (a.i.) ha ${ }^{-1}$. Moreover, the results showed that application of mesosulfuron-methyl + iodosulfuron at doses higher than $9 \mathrm{~g}$ a.i. ha $^{-1}$ changed the shape of the chlorophyll fluorescence induction curve (Kautsky curve) in littleseed canarygrass at 7 DAS while herbicide doses of mesosulfuron-methyl + iodosulfuron did not change the shape of the Kautsky curve in wild oat. In addition, the Kautsky curve was observed to have an approximate permanent drop for littleseed canarygrass species at $2 \mathrm{DAS}$ by pinoxaden. Comparing the fluorescence parameters in wild oat and littleseed canarygrass treated with two herbicides showed that $\mathrm{F}_{\mathrm{v}} / \mathrm{F}_{\mathrm{m}}$. the maximum quantum efficiency of PSII and $\mathrm{F}_{\mathrm{v},}$, variable fluorescence at the $\mathrm{J}$ step of littleseed canarygrass decreased more than the mentioned parameters in wild oat. Furthermore, there was a strong relationship ranging from 0.53 to 0.79 between dry weights after 4 weeks and fluorescence parameters at 7 DAS depending on the herbicide type and weed species. Applying fluorescence parameters a few days after treatment to predict biomass production can be a defining criterion in research and development stages of herbicides to eliminate the need for whole plant bioassay. This method can also be applied to shorten the bioassay screening period and function as a suitable and cost effective indicator for monitoring of ACCase and ALS inhibitors. This approach also demonstrates serious damages to plant photosynthesis apparatus on crop during herbicide misapplication.
\end{abstract}

Keywords: pinoxaden, mesosulfuron-methyl + iodosulfuron, Kautsky curve.

RESUMO - A medição da fluorescência da clorofila é uma técnica de pesquisa precisa que pode ser usada para o estudo do efeito de herbicidas com diferentes modos de ação no aparato fotossintético. O objetivo deste projeto foi estudar a
${ }^{1}$ Department of Agrotechnology, Faculty of Agriculture, Ferdowsi University of Mashhad, Mashhad, Iran.
Copyright: This is an open-access article distributed under the terms of the Creative Commons Attribution License, which permits unrestricted use, distribution, and reproduction in any medium, provided that the original author and source are credited.

\section{<reza-ghorbani@um.ac.ir>}

Received: July 19, 2017

Approved: February 27, 2018

\section{(c) (1)}


variação da curva de indução de fluorescência (curva de Kautsky) e suas variáveis afetadas pelos herbicidas pinoxaden (inibidor da ACCase) e mesosulfuron-methyl + iodosulfuron (inibidores da ALS) na erva-cabecinha (Phalaris minor Retz.) e no aveião (Avena ludoviciana Durieu). Este estudo foi realizado na casa de vegetação do College of Agriculture, Ferdowsi University of Mashhad, durante o ano de 2013. Os experimentos foram feitos em delineamento inteiramente casualizado, na forma de avaliação dose-resposta, com seis doses de cada herbicida e um controle não tratado. A eficiência quântica máxima do fotossistema II (PSII) foi medida 1, 2, 3, 5 e 7 dias após a pulverização (DAS). Os resultados indicaram que houve diferenças nos parâmetros estimados de DE, de acordo com os tipos de herbicidas ou espécies de plantas daninhas. Por exemplo, a $D E_{90}$ variou de 11,67 a 28,61 g de ingrediente ativo (i.a.) ha ${ }^{-1}$. Além disso, os resultados mostraram que a aplicação de mesosulfuron-methyl + iodosulfuron em doses superiores a $9 \mathrm{~g}$ i.a. ha-1 modificou a forma da curva de indução da fluorescência da clorofila (curva de Kautsky) na erva-cabecinha aos 7 DAS, enquanto as doses dos herbicidas mesosulfuron-methyl + iodosulfuron não alteraram a forma da curva de Kautsky no aveião. Além disso, observou-se queda permanente aproximada na curva de Kautsky para a espécie erva-cabecinha aos 2 DAS, em função do pinoxaden. A comparação dos parâmetros de fluorescência no aveião e na ervacabecinha, tratados com dois herbicidas, mostrou que Fv/Fm, eficiência quântica máxima do PSII e Fvj e fluorescência variável no passo $J$ da erva-cabecinha tiveram maior redução do que os mesmos parâmetros para o aveião. Além disso, houve forte relação (com variação de 0,53 a 0,79) entre os pesos secos após quatro semanas e os parâmetros de fluorescência aos 7 DAS, dependendo do tipo de herbicida e da espécie de planta daninha. A aplicação de parâmetros de fluorescência alguns dias após o tratamento para prever a produção de biomassa pode ser um critério de definição em estádios de pesquisa e desenvolvimento de herbicidas para eliminar a necessidade de bioensaio com a planta inteira. Esse método também pode ser aplicado para encurtar o período de rastreio do bioensaio e funcionar como um indicador adequado e rentável para o monitoramento dos inibidores da ACCase e da ALS. Essa abordagem também demonstra sérios danos ao aparato fotossintético das plantas na cultura durante a aplicação incorreta do herbicida.

Palavras-chave: pinoxaden, mesosulfuron-methyl + iodosulfuron, curva de Kautsky.

\section{INTRODUCTION}

Pinoxaden herbicide has been developed to be used in both wheat and barley for controlling grassy weeds. Pinoxaden inhibits the acetyl-CoA carboxylase (ACCase) enzyme which catalyzes the first step of fatty acid synthesis and improves membrane integrity. This herbicide is absorbed through the foliage and phloem transport to the growing point where they inhibit meristematic activity (Yu et al., 2007). Mesosulfuron-methyl+iodosulfuron herbicide inhibits enzyme activity of ALS (Acetolactate Synthase) in the biosynthesis of branch-chain amino acids (valine, leucine, and isoleucine). This class of chemicals affects seedling growth. Older plants exhibit signs of malformation, stunting and reduced seed production. Weeds get resistant to ALS inhibitors rather quickly, presumably because these herbicides have a single mode of action and many of them have long residual activity. Concern is now directed towards developing a technology to detect very low concentrations of ALS inhibitors in the environment and their effects on plant and animal health (Whitcomb, 1999). Cechin et al. (2016) declared that the resistant biotypes presented crossed resistance to herbicides that inhibit the ALS enzyme, where the control can be efficient with the use of herbicides with different action mechanisms.

Chlorophyll fluorescence is a highly sensitive and rapid method to obtain valuable information about the photosynthetic apparatus of plants which can be used to for studying the effect of PSIIinhibiting herbicides and herbicides with other modes of action (Christensen et al., 2003), resistant test as a new method for an accelerated detection (Kaiser et al., 2013) and herbicide dose-response (Zhang et al., 2015).

Generally, the light energy trapped via chlorophylls in PSII and used to produce the photosynthetic power (photochemical energy) and excess energy is released as non-photochemical energy such as heat and chlorophyll fluorescence (Dayan and Zaccaro, 2012). These processes (photochemical reaction, heat and fluorescence) compete together, and increase in the efficacy of one leads to decrease in yields of the other two (Maxwell and Johnson, 2000). The wavelength 
of fluorescence is longer than that of absorbed light. Thus, fluorescence yield can be quantified by exposing a leaf to light of a defined wavelength and then comparing it with the measurement of the re-emitted light that has a longer wavelength (Maxwell and Johnson, 2000). The total amount of chlorophyll fluorescence is small (1-2\% of absorbed light) (Maxwell and Johnson, 2000). Illumination of healthy dark-adapted leaves at a wavelength of $650 \mathrm{~nm}$ provides a rise in amounts of chlorophyll fluorescence emission with some characteristic phases. There are three phases based on the O, J, I, and P steps. These phases primarily indicate photochemical events related to PSII (Govindje, 1995). The three phases are defined as follows: the O-J phase, complete reduction of the primary electron acceptor $Q_{A}$ of PSII takes place within the range of $50 \mu$ s to $2 \mathrm{~ms}$, the J-I phase corresponds to electron transfer from $Q_{A}$ to $Q_{B}$ which occurs between 2 to $30 \mathrm{~ms}$, and the I-P phase corresponds to the release of fluorescence quenching by the oxidized plastoquinone pool which takes place within the range of 30-500 ms (Force et al., 2003; Strasser and Stirbet, 2001). As previously mentioned, illumination of the dark-adapted leaves produces a rise in fluorescence from a ground state $\left(F_{o}\right)$ at the $O$ step to its maximum value $\left(F_{m}\right)$ at the $P$ step within 1 second (Figure 1). Under this condition, $Q_{A}$ is completely reduced and the value of $F_{v} / F_{m}$ can then be determined, which is approximately equal to 0.83 in all plants, independent of species (Appenroth et al., 2001; Force et al., 2003).

Among the parameters derived from the OJIP steps of the fluorescence induction curve, relative changes at the $J$ step (e.g., $\left.\left[F_{v j}=\left(F_{m}-F_{j}\right) / F_{m}\right]\right)$ proved to be a useful parameter to discern effects of herbicides with different modes of action (Christensen et al., 2003; Abbaspoor and Streibig, 2005, 2007) (Figure 1). The shape of the Kautsky curve is affected by various stress factors such as ambient illumination, nutrient supply, temperature and water stress, pathogens and herbicides, etc. (Abash et al., 1985; Daley, 1995). In addition, fluorescence induction kinetics can be altered by many inhibitors of metabolic processes that are not directly involved in photosynthesis. The shape of the Kautsky curve and the derived fluorescence parameters of Arabidopsis thaliana seedlings are influenced by herbicides Asulam, Bifenox, 2,4-D, Diclofopmethyl, Glyphosate, and Imazapyr, which did not have a direct impact on photosynthesis (Barbagallo et al., 2003).

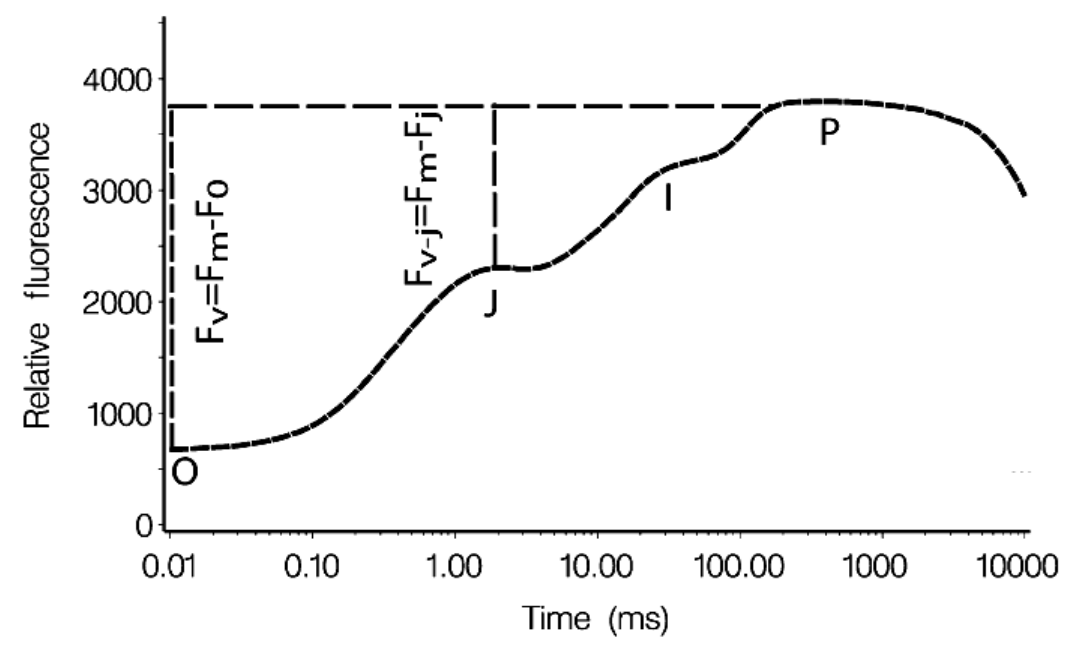

The Kautsky curve rise from $\mathrm{O}$ to $\mathrm{P}$ levels is characterized by the OJIP steps reflecting PSII electron transport from water to PQ pool.

Figure 1 - Kautsky curve recorded with Handy PEA instrument in 30 minutes dark adapted leaf.

This technique is a highly sensitive, noninvasive method to assess the photosynthetic electron transfer chain from PS II to PS I (Tongra et al., 2011). Other benefits of this method include its possibility and the adaptability of using a portable instrument with rapid collection of data and advanced software enabling statistical analysis (Klem et al., 2002). The method can be used for the study of the effect of PSII-inhibiting herbicides as well as herbicides with other modes of action (Christensen et al., 2003). 
The aims of the present research were to investigate how rapidly two herbicides with various modes of action affect the shape of the Kautsky curve, defined by various fluorescence parameters in weed species and whether possible herbicide variations can be observed in the shape of the Kautsky curve as a function of time after being exposed to herbicides. A further objective was to relate temporal fluorescence parameters to biomass at the termination of the experiments with the aim of demonstrating the analysis of fluorescence emission parameters as a cost-efficient method for the rapid screening of herbicide activity.

\section{MATERIAL AND METHODS}

\section{Plants and growth conditions in greenhouse}

Wild oat seeds were directly sown in pots. However, littleseed canarygrass seeds were first treated with sulfuric acid $98 \%$ and then similar to wild oat seeds planted in $1 \mathrm{~L}$ plastic pots filled with a mixture of clay, loam soil, and sand $(1: 1: 1 \mathrm{v} / \mathrm{v} / \mathrm{v})$. The pots were watered at two-day intervals. The seedlings were thinned to 4 plants per pot. The experiments were conducted for a threemonth period from November to January 2013 at the Research Greenhouse, Faculty of Agriculture, Ferdowsi University of Mashhad, Iran.

\section{Chemical treatments and experimental designs}

Two independent experiments were separately carried out for wild oat and littleseed canarygrass. In the first experiment, pinoxaden and mesosulfuron-methyl + iodosulfuron were tested on wild oat and in the second experiment both of them were tested on littleseed canarygrass, simultaneously. Each herbicide included a dose-response test with six doses plus untreated control. The dose ranges included the recommended dose, 2.25, 4.5, 9, 13.5, 18 and $24 \mathrm{~g}$ a.i. ha ${ }^{-1}$ for mesosulfuron-methyl+iodosulfuron (Atlantis OD, Bayer Crop Science, Germany) and 2.81, 5.6, 11.25, 22.5, 33.75 and $45 \mathrm{~g}$ a.i. ha $^{-1}$ for pinoxaden (Axial 10\% EC, EC; Syngenta, Switzerland). The spray treatments were applied at three to four-leaf stage by using an overhead trolley sprayer (Matabi 121030 Super Agro 20 L sprayer; Agratech Services-Crop Spraying Equipment, Rossendale, UK), equipped with an 8002 flat fan nozzle tip delivering $200 \mathrm{~L} \mathrm{ha}^{-1}$ at 2 bar spray pressure. Altogether, 24 treatments were used for littleseed canarygrass and wild oat with four replications (i.e. totally 96 experimental units including control) arranged in a completely randomized layout.

\section{Chlorophyll fluorescence assays}

The chlorophyll fluorescence was measured at 1, 2, 3, 5 and 7 DAS, using a portable chlorophyll fluorometer (Handy-PEA; Hansatech Instruments, King's Lynn, Norfolk, UK) which emits $650 \mathrm{~nm}$ light wavelength with an intensity of $3000 \mu \mathrm{mol}$ photons $\mathrm{m}^{-2} \mathrm{~s}^{-1}$ for $10 \mathrm{~s}$. The measurements were performed on dark-adapted leaves (30 min dark adaptation by covering the leaves with a clip). The Kautsky curves were obtained by the Microsoft Excel Program. The parameters derived from the Kautsky curve in Figure 1 were $F_{v j}$, the relative changes at the $J$ step $\left[F_{v j}=\left(F_{m}-F_{v j}\right) / F_{m}\right]$, Area, the area between Kautsky curve and maximum fluorescence $\left(F_{m}\right)$, and $F_{v} / F_{m}$, the maximum quantum efficiency of PSII $\left[F_{v} / F_{m}\left(F_{m}-F_{0}\right) / F_{m}\right]$. Moreover, the shoot organs of the experimental units were harvested and oven-dried at $75^{\circ} \mathrm{C}$ for $48 \mathrm{~h}$, and then weighed four weeks after spraying. The greenhouse temperature varied from $18-25^{\circ} \mathrm{C}$ during the day and $14-21^{\circ} \mathrm{C}$ at night.

\section{Statistical analysis}

A log-logistic curve was used to describe dose-response relationships (Ritz and Streibig, 2005):

$$
f(x(b, c, d, e))=\frac{d-c}{1+e^{[b(\log (x)-\log (e))]}}+c
$$

In this formula, the parameter e in logistic model denoted to $\mathrm{ED}_{50}$. The parameter $\mathrm{b}$ denotes the relative slope around e. The parameters $\mathrm{c}$ and $\mathrm{d}$ are the lower and upper limits. The goodnessof-ût was assessed by graphical analyses of residuals and F test for lack-of-ût. Moreover, optimal 
Box-Cox transform-both-sides approach was used to modify homogeneity of the response as needed (Ritz and Streibig 2005).

\section{RESULTS AND DISCUTTION}

\section{Dose-response greenhouse studies}

Parameters derived from regression analysis of the dose-response curves for littleseed canarygrass and wild oat are described in Table 1. Results obtained from both experiments showed pinoxaden was more potent than mesosulfuron-methyl + iodosulfuron against both species, hence; lower doses of pinoxaden were needed for $50 \%$ or $90 \%$ controlling of both species in comparison with mesosulfuron-methyl + iodosulfuron application (Table 1). For example, only 57\% of recommended dose of pinoxaden (45 $\mathrm{g}$ a.i. $\mathrm{ha}^{-1}$ ) was required for $90 \%$ controlling of littleseed canarygrass while $69 \%$ of recommended dose of mesosulfuron-methyl + iodosulfuron $\left(24 \mathrm{~g}\right.$ a.i. ha $\left.{ }^{1}\right)$ was needed for this control level. Finally, we recommend using pinoxaden instead of mesosulfuronmethyl + iodosulfuron for adequate weed control. Besides, $\mathrm{ED}_{50}, \mathrm{ED}_{90}$ differed in values based on weed species. For instance, the $\mathrm{ED}_{50}$ values of mesosulfuron-methyl + iodosulfuron were 4.51 and $6.18 \mathrm{~g}$ a.i. $\mathrm{ha}^{-1}$ for littleseed canarygrass and wild oat, respectively. These results can be related to the difference in the properties of species.

Table 1 - Summary of dose-response analysis of dry matter at 30 days after spray (DAS) (three to four true leaf stage) for both of experiments

\begin{tabular}{|c|c|c|c|c|c|c|}
\hline Species & Herbicide & $\begin{array}{c}\text { Upper } \\
\text { limit } \pm \mathrm{SE}^{(1)}\end{array}$ & $\begin{array}{c}\text { Lower } \\
\text { limit } \pm \mathrm{SE}\end{array}$ & $\mathrm{ED}_{50}{ }^{(2)} \pm \mathrm{SE}$ & $\mathrm{ED}_{90}{ }^{(2)} \pm \mathrm{SE}$ & $\begin{array}{c}\text { Lack of fit test } \\
(5 \%)\end{array}$ \\
\hline \multicolumn{7}{|c|}{ First experiment } \\
\hline \multirow{2}{*}{ Wild oat } & Pinoxaden & $0.68 \pm 0.03$ & $0.11 \pm 0.18$ & $6.97 \pm 15.3$ & $28.61 \pm 32.1$ & $0.62^{\mathrm{NS}}$ \\
\hline & $\begin{array}{l}\text { Mesosulfuron- } \\
\text { methyl+iodosulfuron }\end{array}$ & $0.68 \pm 0.03$ & $0.23 \pm 0.04$ & $6.18 \pm 0.5$ & $18.91 \pm 2.99$ & $0.25^{\mathrm{NS}}$ \\
\hline \multicolumn{7}{|c|}{ Second experiment } \\
\hline \multirow{2}{*}{ Littleseedcanarygrass } & Pinoxaden & $1.04 \pm 0.08$ & $0.58 \pm 0.07$ & $3.28 \pm 1.33$ & $25.68 \pm 4.99$ & 0.53 NS \\
\hline & $\begin{array}{l}\text { Mesosulfuron- } \\
\text { methyl+iodosulfuron }\end{array}$ & $1.02 \pm 0.14$ & $0.69 \pm 0.24$ & $4.51 \pm 1.29$ & $16.67 \pm 3.34$ & $0.39^{\mathrm{NS}}$ \\
\hline
\end{tabular}

(1) $\mathrm{SE}=$ Standard Error, (2) $\mathrm{ED}_{50}$ or $\mathrm{ED}_{90}=$ Effective Dose at 50 or 90 percent, N not significant at the $5 \%$ level. In both experiments the test for lack of fit was not significant, indicating that the logistic model was able to describe the data better than an ordinary ANOVA.

\section{The kautsky curves}

The effect of pinoxaden and mesosulfuron-methyl + iodosulfuron on the shape of the Kautsky curves for littleseed canarygrass and wild oat are demonstrated in Figure 2. Pinoxaden affected the Kautsky curves and changed them to horizontal lines 5 DAS at $11.25 \mathrm{~g}$ active ingredient $\left(\right.$ a.i. $\left.\mathrm{ha}^{-1}\right)$ however; this change was at higher doses in wild oat (first experiment). Mesosulfuronmethyl + iodosulfuron had almost no impact on the Kautsky curves at all concentrations in wild oat (Figure 2E). In the second experiment, all the doses affected Kautsky curves in littleseed canarygrass 2 DAS while the shape of the Kautsky curves was influenced by mesosulfuronmethyl + iodosulfuron between 9-24 g a.i. ha ${ }^{-1} 7$ DAS (Figure 2D and F). Generally, littleseed canarygrass seems more sensitive to mesosulfuron-methyl + iodosulfuron and especially pinoxaden application compared to wild oat (Figure 2).

\section{The fluorescence parameters}

To describe changes in the shape of the Kautsky curves in Figure 2, three important fluorescence parameters, including $\mathrm{F}_{\mathrm{v}} / \mathrm{F}_{\mathrm{m}}$, Area, and $\mathrm{F}_{\mathrm{vj}}$ were plotted at the range of doses of 

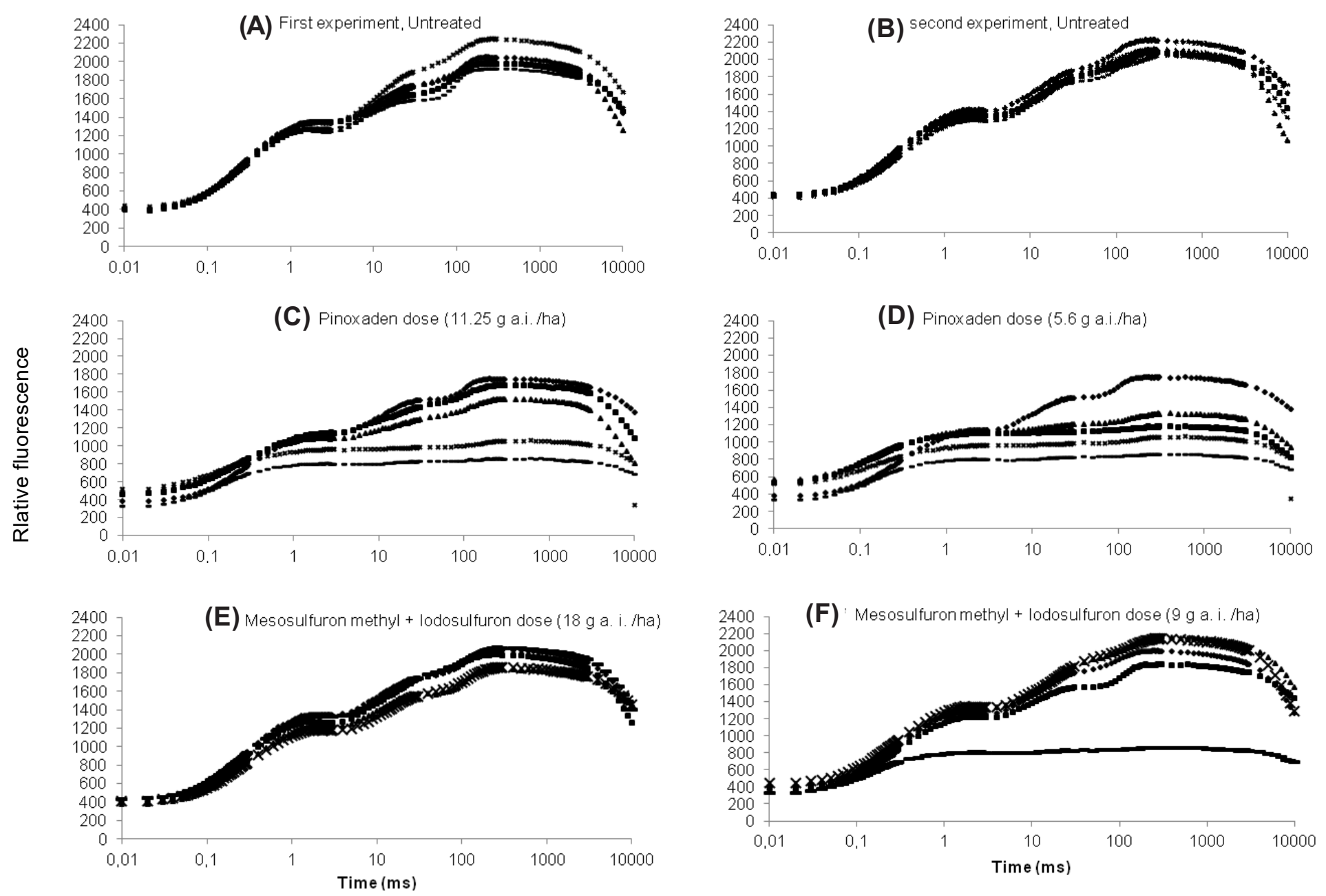

$\bullet 1 \mathrm{DAS}-2 \mathrm{DAS} \boldsymbol{\Delta} 3 \mathrm{DAS} \times 5 \mathrm{DAS}-7 \mathrm{DAS}$

DAS: days after spraying.

Kautsky curve for wild oat (left) (A, C and E) and littleseed canarygrass (right) (B, D and F), respectively. Each curve is the mean of four replications for rest of the doses.

Figure 2 - Effect of herbicides application on the shape of the Kautsky curve.

applied herbicides (Figure 3). The value of the $\mathrm{F}_{\mathrm{v}} / \mathrm{F}_{\mathrm{m}}$ parameter was close to 0.83 in wild oat and remained consistent during the experimental period and decreased in littleseed canarygrass at 3 DAS. Also, the values of $\mathrm{F}_{\mathrm{Vj}}$ and Area somewhat fluctuated during the course of the experiment (Figure 3).

Figure 3 indicated that $\mathrm{F}_{\mathrm{v}} / \mathrm{F}_{\mathrm{m}}$, is almost a stable parameter compared with Area and $\mathrm{F}_{\mathrm{vj}}$, However, $\mathrm{F}_{\mathrm{v}} / \mathrm{F}_{\mathrm{m}}$ was not sensitive enough to trace minor herbicide effects in wild oat. $\mathrm{F}_{\mathrm{vj}}$ and Area were decreased by pinoxaden and mesosulfuron-methyl+iodosulfuron in both species (Figure 3).

\section{The relationship between fluorescence parameter and dry weight}

The relationship between dry matter (30 DAS) and the selected fluorescence parameters (7 DAS) for wild oat and littleseed canarygrass is shown in Figure 4. A linear regression of dry matter on fluorescence parameters was fitted to the data. Results showed that the relationship between the fluorescence parameters and dry matter was evident. The graphs showed, $F_{v} / F_{m}$ was more affected by the lipophilic pinoxaden with $\log \mathrm{K}_{\mathrm{ow}}=3.2$ than by mesosulfuronmethyl+iodosulfuron with $\log \mathrm{K}_{\mathrm{ow}}=1.07$ (Figures 3 and 4). 

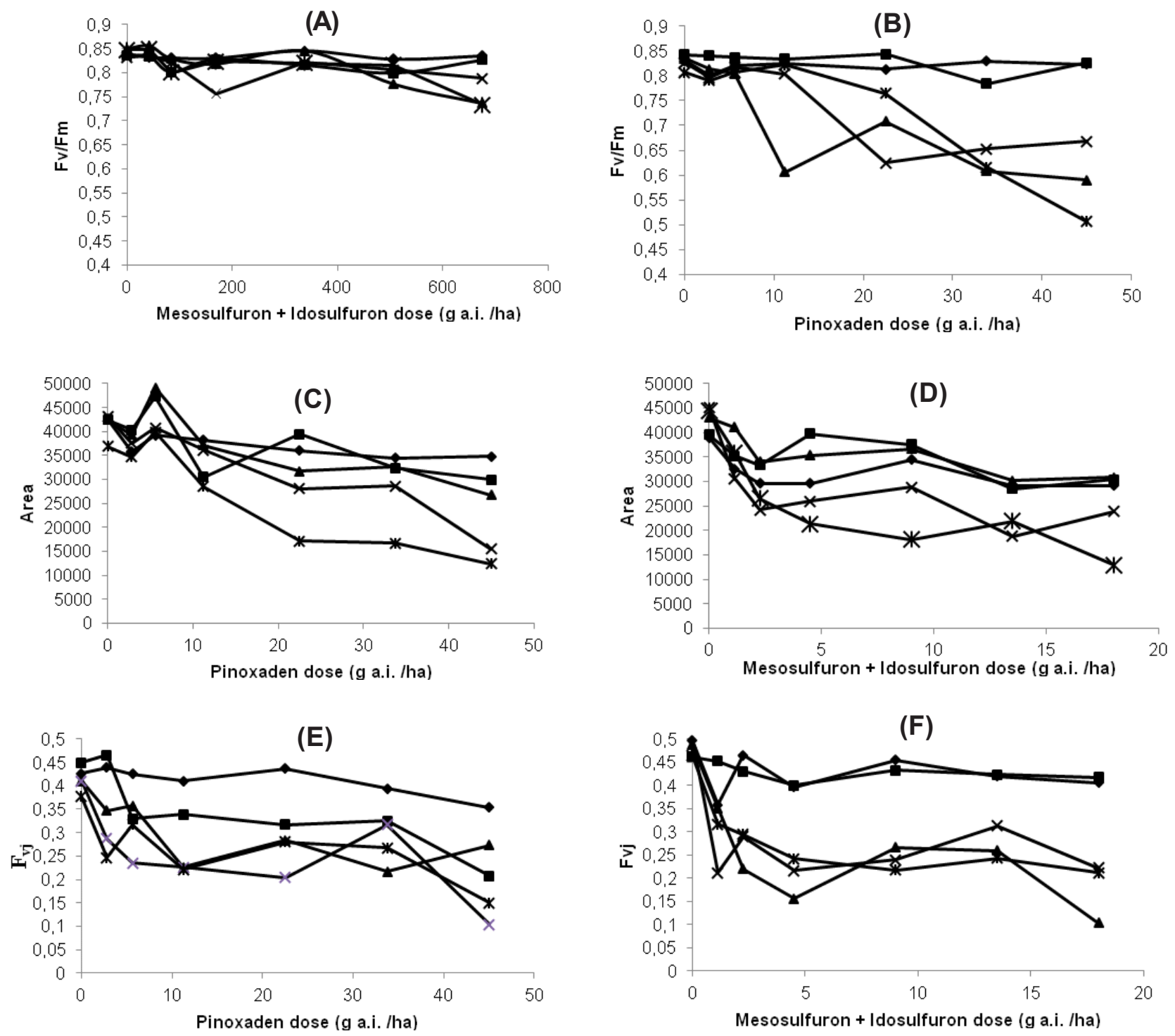

$\leftarrow 1$ DAS $\rightarrow 2$ DAS $\longleftarrow 3$ DAS $\multimap 5$ DAS $\longleftarrow$ DAS

DAS: days after spraying.

Figure 3 - Effect of mesosulfuron-methyl+iodosulfuron on Fv/Fm in wild oat (A), pinoxaden on Fv/Fm and area in littleseed canarygrass and wild oat, respectively (B-C), mesosulfuron-methyl+iodosulfuron effect on area in littleseed canarygrass (D), and pinoxaden and mesosulfuron-methyl+iodosulfuron effect on Fvj in wild oat and littleseed canarygrass, respectively (E-F).

The results of our research showed that pinoxaden was more effective in both experiments compared to mesosulfuron-methyl + iodosulfuron. Zand et al. (2007) obtained the complete control of wild oat using pinoxaden at all doses. Also, they found that population and biomass reduction of weeds decreased 86.24 and $50.5 \%$ by mesosulfuron-methyl + iodosulfuron, respectively. In addition, the results showed that the shape of the Kautsky curves changed by pinoxaden more and earlier compared to mesosulfuron-methyl + iodosulfuron. Cedergreen et al. (2005) stated the rapidity of absorption of herbicides and the subsequent effect on fluorescence parameters to be positively related to physicochemical properties such as $\log \mathrm{K}_{\mathrm{ow}}$. Yet in another study, Bromilow and Chamberlain (1995) found that uptake depend on lipophilicity of the herbicide molecule. Hence, lipophilic compounds diffuse more quickly into plant cells than do hydrophilic compounds (Trapp, 2000). It seems that pinoxaden with higher $\log \mathrm{K}_{\mathrm{ow}}$ of 3.2 compared to mesosulfuronmethyl+iodosulfuron uptake in shorter time and has greater influence on the Kautsky curves. 

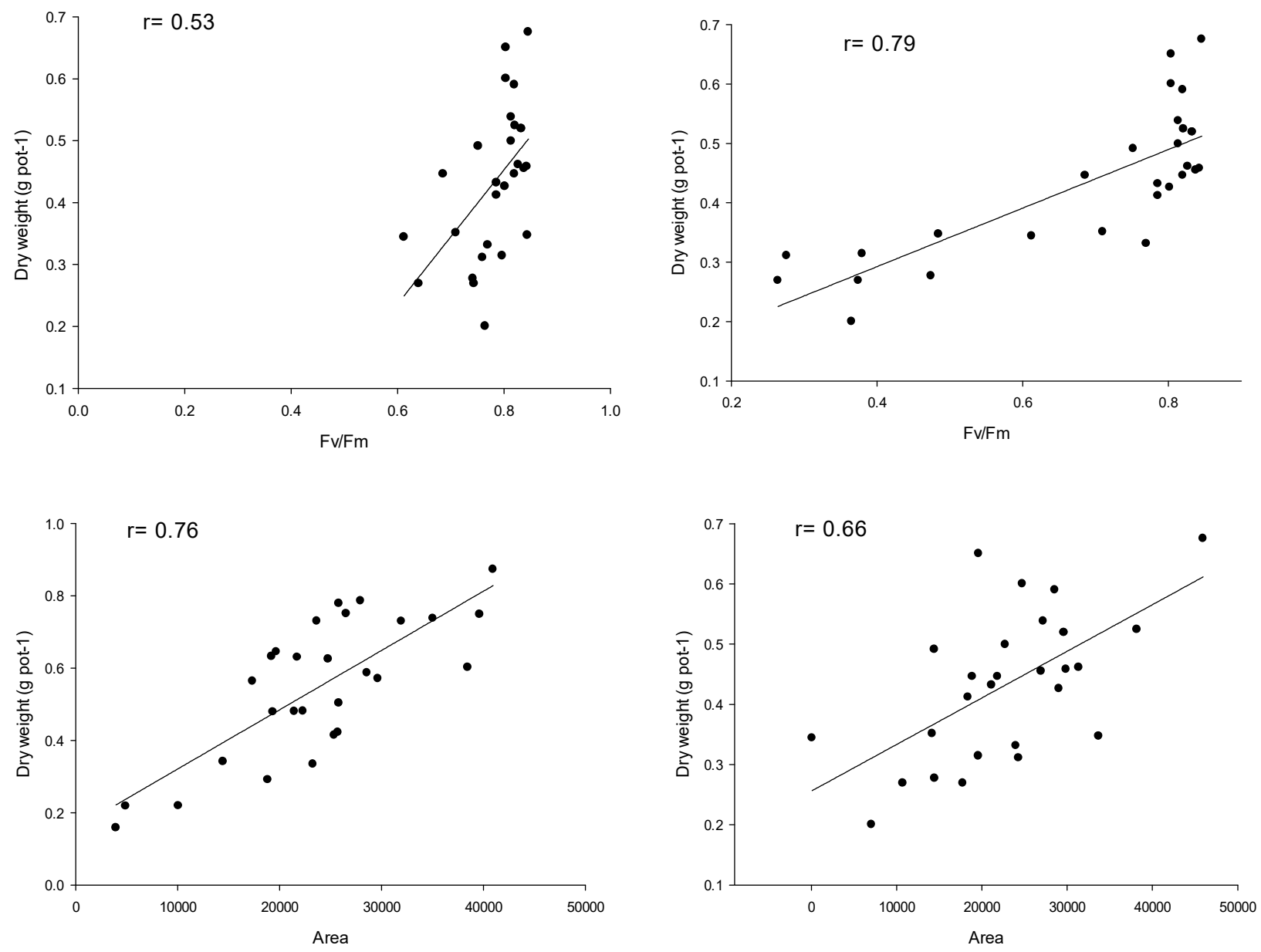

Left, wild oat sprayed by pinoxaden in the first experiment; right, littleseed canarygrass sprayed by mesosulfuron-methyl+iodosulfuron in the second experiment.

Figure 4 - The relationship between dry weight and chlorophyll fluorescence parameters $\left(\mathrm{F}_{\mathrm{v}} / \mathrm{F}_{\mathrm{m}}, \mathrm{F}_{\mathrm{vj}}\right.$ and area) at 7 DAS in both experiments.

Moreover, The Kautsky curves of littleseed canarygrass was more affected by herbicides. Differences between weed species in structural, morphological and physiological properties could be involved in such effects. Abbaspoor et al. (2006) and Abbaspoor and Streibig (2007) found that it is also possible for the Kautsky curve to be affected by several factors including different phenological stages of plant and environmental conditions such as temperature, water stress, nutrient supply and weed species.

In spite of the fact that pinoxaden and mesosulfuron-methyl + iodosulfuron were not PSII inhibitors, they influenced on the shape of the Kautsky curves (Figure 2). These findings are in agreement with the response of white mustard (Sinapis alba) treated with bentazone, flurochloridone and glyphosate (Christensen et al., 2003), lambsquarters (Chenopodium album) treated with atrazine (Hiraki et al., 2003), wild mustard (Sinapis arvensis) treated with dicamba + 2, 4-D (Avarseji et al., 2012) and soybean (Glycine max) exposed to dark chilling (van Heerden et al., 2003). The results also showed that the parameters derived from the Kautsky curves had different variations. Furthermore, according to the results, the $F_{v} / F_{m}$ parameter was stable whereas $\mathrm{F}_{\mathrm{vj}}$ and Area reduced in the both species. Abbaspoor and Streibig (2007) proved that the relative changes at the $J$ step $\left(F_{v j}\right)$ were useful parameters to discern effects of herbicides with other modes of action. It was also shown that $\mathrm{F}_{\mathrm{v}} / \mathrm{F}_{\mathrm{m}}$ may not be the most sensitive parameter when early detection of fluorescence emission changes is required for herbicides with modes of action other than that of PSII inhibition (Christensen et al., 2003; Abbaspoor and Streibig, 2005, 2007). Abbaspoor et al. (2006) also reported that by spraying desmedipham, phenmedipham or a mixture of both, the $\mathrm{F}_{\mathrm{vj}}$ and Area parameters were much more sensitive than the $\mathrm{F}_{\mathrm{v}} / \mathrm{F}_{\mathrm{m}}$ parameter 
measured in black nightshade and sugar beet. Furthermore, based on the results, a good relationship was observed between dry matter and the fluorescence parameters. Similar relation was also previously reported between the fluorescence parameters and dry matter for bentazone, desmedipham, and phenmedipham (a PSII inhibitor) (Christensen et al., 2003; Abbaspoor and Streibig, 2007) and clodinafop (non-PSII inhibitors) (Abbaspoor and Streibig, 2005). Based on these results, using such fluorescence parameters may suggest a rapid, noninvasive, costeffective option to eliminate the need for whole plant bioassay screenings.

\section{ACKNOWLEDGMENTS}

We would like to thank the Faculty of Agriculture, Ferdowsi University of Mashhad, Mashhad, Iran for financial support and providing experimental facilities in this research.

\section{REFERENCES}

Abash D, Percival M, Baker N. Rapid chlorophyll fluorescence technique for the study of penetration of photosynthetically active herbicides into leaf tissue. Weed Res. 1985;25(5):389-95.

Abbaspoor M, Streibig JC. Clodinafop changes the chlorophyll fluorescence induction curve. Weed Sci. 2005;53(1):1-9.

Abbaspoor M, Streibig JC. Monitoring the efficacy and metabolism of phenylcarbamates in sugar beet and black nightshade by chlorophyll fluorescence parameters. Pest Manag Sci. 2007;63(6):576-85.

Abbaspoor M, Teicher HB, Streibig JC. The effect of root-absorbed PSII inhibitors on Kautsky curve parameters in sugar beet. Weed Res. 2006;46(3):226-35.

Appenroth K-J, Stöckel J, Srivastava A, Strasser RJ Multiple effects of chromate on the photosynthetic apparatus of Spirodela polyrhiza as probed by OJIP chlorophyll a fluorescence measurements. Environ. Pollut. 2001;115(1):49-64.

Avarseji Z, RashedMohassel MH, Nezami A, Abbaspoor M, Nassiri Mahallati M. Dicamba+2, 4-D affects the shape of the Kautsky curves in wild mustard (Sinapis arvensis). Plant Knowl J. 2012;1(2):41-5.

Barbagallo RP, Oxborough K, Pallett KE, Baker NR. Rapid, noninvasive screening for perturbations of metabolism and plant growth using chlorophyll fluorescence imaging. Plant Physiol. 2003;132(2):485-93.

Bromilow RH, Chamberlain K. Principles governing uptake and transport of chemicals. In: Trapp S, Mc Farlane C, editors. Plant contamination: modeling and simulation of organic chemical processes. Boca Raton: Lewis Publishers; 1995. p.23-8.

Cechin J, Vargas L, Agostinetto D, Zimmer V, Pertile M, Garcia JR. Resistence of radish biotypes to iodosulfuron and alternative control. Planta Daninha. 2016;34(1):151-60.

Cedergreen N, Andersen L, Olesen CF, Spliid HH, Streibig JC. Does the effect of herbicide pulse exposure on aquatic plants depend on Kow or mode of action? Aquat Toxicol. 2005;71(3):261-71.

Christensen MG, Teicher HB, Streibig JC. Linking fluorescence induction curve and biomass in herbicide screening. Pest Manag Sci. 2003;59(12):1303-10.

Daley PF. Chlorophyll fluorescence analysis and imaging in plant stress and disease. Can J Plant Pathol. 1995;17(2):167-73.

Dayan FE, Zaccaro MLM. Chlorophyll fluorescence as a marker for herbicide mechanisms of action. Pestic Biochem Physiol. 2012;102(3):189-97.

Force L, Critchley C, van Rensen JJS. New fluorescence parameters for monitoring photosynthesis in plants. Photosynth Res. 2003;78(1):17-33.

Govindje E. Sixty-Three years since kautsky: Chlorophyll a fluorescence. Funct Plant Biol. 1995;22(2):131-60.

Hiraki M, van Rensen JJ, Vredenberg WJ, Wakabayashi K. Characterization of the alterations of the chlorophyll a fluorescence induction curve after addition of photosystem II inhibiting herbicides. Photosynth Res. 2003;78(1):35-46. 
Kaiser YI, Menegat A, Gerhards R. Chlorophyll fluorescence imaging: a new method for rapid detection of herbicide resistance in Alopecurus myosuroides. Weed Res. 2013;53(6):399-406.

Klem K, Špundová M, Nauš J, Váòová M, Masojídek J, Tomek P. Comparison of chlorophyll fluorescence and whole-plant bioassays of isoproturon. Weed Res. 2002;42(5):335-41.

Maxwell K, Johnson GN. Chlorophyll fluorescence a practical guide. J Exp Bot. 2000;51(345):659-68.

Ritz C, Streibig JC. Bioassay analysis using. J Stat Softw. 2005;12(5):1-22.

Strasser RJ, Stirbet AD. Estimation of the energetic connectivity of PS II centres in plants using the fluorescence rise O-J-I-P: Fitting of experimental data to three different PS II models. Math. Comput Simul. 2001;56(4):451-62.

Tongra T, Mehta P, Mathur S, Agrawal D, Bharti S, Los DA, et al. Computational analysis of fluorescence induction curves in intact spinach leaves treated at different pH. Biosystems. 2011;103(2):158-63.

Trapp S. Modelling uptake into roots and subsequent translocation of neutral and ionisable organic compounds. Pest Manag Sci. 2000;56(9):767-78.

van Heerden PD, Tsimilli-Michael M, Krüger GH, Strasser RJ. Dark chilling effects on soybean genotypes during vegetative development: parallel studies of CO2 assimilation, chlorophyll a fluorescence kinetics OJIP and nitrogen fixation. Physiol Plant. 2003;117(4):476-91.

Whitcomb CE. An introduction to ALS-inhibiting herbicides. Toxicol Ind Health. 1999;15(1-2):232-40.

Yu Q, Collavo A, Zheng M-Q, Owen M, Sattin M, Powles SB. Diversity of acetyl-coenzyme A carboxylase mutations in resistant Lolium populations: evaluation using clethodim. Plant Physiol. 2007;145(2):547-58.

Zand E, Baghestani MA, Soufizadeh S, Eskandari A, Azar RP, Veysi M, et al. Evaluation of some newly registered herbicides for weed control in wheat (Triticum aestivum L.) in Iran. Crop Protec. 2007;26(9):1349-58.

Zhang CJ, Lim SH, Kim JW, Song JS, Yook MJ, Nah G, et al. Quantifying herbicide dose-response and resistance in Echinochloa spp. by measuring root length in growth pouches. Can. J. Plant Sci. 2015;95(6):1181-92. 